INDEPENDENT JOURNAL OF MANAGEMENT \& PRODUCTION (IJM\&P) http://www.ijmp.jor.br

v. 12, n. 2, March-April 2021 ISSN: 2236-269X

DOI: 10.14807/ijmp.v12i2.1287

\title{
A HYBRID MULTI-CRITERIA DECISION-MAKING APPROACH TO ORDER NATURAL GAS CONSUMING COUNTRIES
}

\author{
Ester Figueiredo Girão \\ IBMEC-RJ, Brazil \\ E-mail: estergirao@hotmail.com
}

Luiz Flavio Autran Monteiro Gomes

IBMEC-RJ, Brazil

E-mail: luiz.gomes@ibmec.edu.br

Submission: $2 / 27 / 2020$

Revision: 5/13/2020

Accept: 6/3/2020

\section{ABSTRACT}

Societies worldwide are committed to moving towards a low carbon economy, and natural gas is considered a transition fuel between fossil (such as gasoline and diesel) and renewable fuels. Based on the relevance of natural gas in this economic transition, this paper demonstrates the application of a hybrid multicriteria decision-making approach to order the natural gas consuming countries. The aim is to support decision-making in the natural gas market, offering elements to prioritize the trade worldwide. The study observed three criteria: consumption variation for years 2014 to 2016; the volume of production in the same period; and proven natural gas reserves in 2016. The data to demonstrate the countries' performance was obtained from a yearly statistic publication of the Brazilian National Agency of Petroleum, Natural Gas, and Biofuels (ANP), released in 2017. Finally, the decision-making methods adopted to assess the criteria were, first, the WINGS method, applied to generate the weights of each criterion. Second, the study adopted the TOPSIS method to pre-select the countries closest to becoming a global consumer of natural gas. After applying the TOPSIS method, a pre-analysis of dominance among alternatives (preselected countries) was conducted, excluding the dominated ones from the list obtained. Third, the PROMÉTHÉE II method was applied to establish the order of the natural gas-consuming countries.

Keywords: natural gas; ordering countries; multi-criteria decision-making; WINGS; TOPSIS; PROMÉTHÉE 
ISSN: $2236-269 X$

DOI: 10.14807/ijmp.v12i2.1287

\section{INTRODUCTION}

Natural gas (NG) is a mixture of light hydrocarbons that remain in the gaseous state when under normal temperature and pressure (Santos, 2002). In nature, NG is found in reservoirs, within porous rocks underground (onshore and offshore), usually accompanied by oil (Faramawy, Zaki \& Sakr, 2016).

According to IEA (2017), NG provides 22\% of the energy used worldwide and accounts for almost a quarter of electricity generation. It plays a crucial role as a raw material for industry. NG is a versatile fuel, and its increasing use is partly due to its environmental benefits compared to other fossil fuels (Mac Kinnon, Brouwer \& Samuelsen, 2018).

The NG market is becoming globalized. As trade increases, so do concerns about NG security, as a supply or demand shock in one region may now have repercussions in another (Iea, 2018). Oil and NG companies have been preparing for a new scenario that will challenge the competitiveness of their traditional business model as societies worldwide are committed to moving toward a low carbon economy (Zhong \& Bazilian, 2018).

From a theoretical point of view, some scholars consider that the liberalization of fuel markets offers energy security and efficiency of allocation of scarce resources in the short term (Radetzki, 1999). Bilgin (2009) and Helen (2010), however, identified that structural and institutional conditions often hinder the fuel market efficiency. They point out that reliable demand forecasts are needed to sustain the real impact of fuel consumption on future generations.

Against this backdrop, this research used a hybrid multi-criteria decision-making approach to order NG consuming countries. The objective of the study was to identify the leading consuming countries, producing relevant information to subsidize the planning and decision-making of producers and others involved in the global NG market. In the multi-criteria approach presented here, the set of criteria was formed by the attributes used as references when contextualizing the national industry in the international scenario.

According to the "Oil, Natural Gas and Biofuels Statistical Yearbook 2017,” published by the ANP - Brazilian National Agency of Petroleum, Natural Gas and Biofuels (ANP, 2017) these attributes are consumption, production, and reserves of NG of each country studied in the yearbook. The set of alternatives was formed by the countries mentioned in the yearbook when there was information on the three attributes. 
INDEPENDENT JOURNAL OF MANAGEMENT \& PRODUCTION (IJM\&P)

http://www.ijmp.jor.br

v. 12, n. 2, March-April 2021

ISSN: 2236-269X

DOI: $10.14807 /$ ijmp.v12i2.1287

Three multi-criteria decision-making methods were applied, starting with the WINGS method, used to establish the weight of each criterion. After that, the TOPSIS method was applied to the set of alternatives, pre-selecting 15 main NG consuming countries, followed by a dominance pre-analysis among them. Finally, the study applied the PROMÉTHÉE II method to the set of alternatives formed after the predominance analysis.

The oil and NG industry represents the currently most used energy sources, essential for society worldwide. This relevance justifies the academic interest in studying this field, particularly promoting better decision-making based on multiple criteria and different groups of stakeholders. This type of study contributes to the search for excellence in planning and management, as well as guiding investment to increase the capacity to meet the demands for the oil and NG industry's development.

\section{THEORETICAL FRAMEWORK}

\subsection{Natural Gas: Composition, Value Chain, and Participation in the Energy Matrix}

The composition of NG may vary according to the field. The variation may occur due to the type of organic matter, the natural processes it was submitted to, regardless of whether it was associated with oil or if processed in industrial units. However, NG consists mainly of methane, ethane, propane, and, to a lesser extent, other methane hydrocarbons ( $\mathrm{CH} 4)$. Typically, NG has low levels of impurities such as nitrogen (N2), carbon dioxide (CO2), water, and sulfur compounds.

Conceptually, the NG value chain follows a similar structure to that of oil and is equally divided into three segments: upstream, midstream, and downstream.

In the upstream segment, 'exploration' is the process of researching the hydrocarbon accumulation, in both onshore and offshore basins. Production is the process of extraction, recovery, and processing of NG on a commercial scale. Exploration is a high-risk process because of the uncertainty of finding a deposit in areas where the geology is not well known, which may require high investments and operating costs.

The midstream segment refers to the choice of how to move NG from the producing field to the consumer market. This is a strategic issue for the NG industry.

Finally, the downstream segment refers to the phase after transportation. It is the distribution process, from the moment the gas is received at the citygates - facilities for pressure reduction and control, measurement, and odorization. From the citygates, NG is routed 
DOI: 10.14807/ijmp.v12i2.1287

through pipelines to various market segments: industrial, commercial, residential, and electricity generation.

Due to the significant impact of NG in various sectors of the economy and worldwide geopolitics, it is crucial to develop strategies for global development in the energy field, considering projects of NG exploration and production, processing, and transportation, seeking to increase supply.

\subsection{Multi-Criteria Decision-Making Methods}

Multi-criteria decision-making (MCDM) methods aim to explain and recommend decisions, contributing to answering questions in complex moments. The MCDM method seeks to make the process as neutral, objective, valid, and transparent as possible, without attaching the decision-maker to a single and true solution (Gomes, Araya \& Carignano, 2004). Thus, MCDM methods apply to many areas to select, order, classify or describe alternatives present in a decision process, when there are multiple qualitative or quantitative criteria (Roy \& Bouyssou, 1993; Romero, 1993; Vincke, 1989). These methods seek to assist a decisionmaking process in which a set of alternatives must be simultaneously analyzed by a group of usually conflicting criteria (Gomes, Araya \& Carignano, 2004).

One of the many classifications for MCDM methods subdivides them as those from 'American School' and those from 'French' or 'European School.' However, there are MCDM methods that do not formally fit into one of these two schools, known as 'hybrid methods' (Gomes; Gomes; Almeida, 2006; Belton; Stewart, 2002; Barba- Romero; Pomerol, 1997). Some of the hybrid methods include the TODIM method (Gomes\& Rangel, 2009; Gomes, Araya \& Carigñano, 2004), the MACBETH method (BANA et al., 2005), and the TOPSIS method (Hwang \& Yoon, 1981).

The most prominent methods of the 'French School' are the ELECTRE (Roy \& Bouyssou, 1993) and the PROMÉTHÉE (Brans, Vincke \& Mareschal, 1986). The main methods of the 'American School' are the Analytic Hierarchy Process (AHP) (Saaty, 1980) and the Multi-attribute Utility Theory (MAUT) (Keeney \& Raiffa, 1993).

\subsection{Multi-Criteria Decision-Making Methods Applied in the Industry of Oil and Natural Gas}

According to Neves, Pereira, and Costa (2015), the use of multi-criteria decisionmaking methods in the planning and management of the oil and NG industry is a practice that has evolved over the years. However, the MCDM is still little explored in topics such as NG, 
DOI: 10.14807/ijmp.v12i2.1287

downstream segments of the value chain, and offshore. According to the authors, the first articles on these methods started to be published in 1996. The descriptors used in the research by Neves, Pereira, and Costa (2015) were the energy source, the segment of the value chain, and geographical positioning. The research selected 48 articles from Scopus or ISI Web of Knowledge, $41.67 \%$ of them referred to oil, $35.42 \%$ oil and NG, and $22.92 \%$ referred to NG.

Neves, Pereira, and Costa (2015) show that, among the analyzed articles, the AHP method was the most used for planning and management in the oil and NG industry, representing $60.94 \%$ of the observations. As for the other methods, the authors found that $1.56 \%$ of the studies adopted PROMÉTHÉE II, and 3.13\% used TOPSIS.

In the research by Gomes and Maranhão (2008), the authors sought to learn the best option in a set of alternatives regarding the destination of recently discovered natural gas reservoirs in the Santos Basin, more specifically in the Mexilhão field. The authors adopted TODIM, a discrete MCDM method based on the Prospect Theory. The TODIM method proved to be very useful in recommending upstream project options, allowing clear identification of significant alternatives, given the scenarios and criteria tested.

According to Khosravanian and Wood (2016), oil and NG companies make several decisions when selecting an appropriate well completion project - a process that consists of equipping the well for oil or gas production or for fluid injection in reservoirs. The aim of selecting alternatives for well completion projects is to achieve higher productivity, with lower investments, lower maintenance costs, and less time to end the process. This is often a strategic decision that forces the operator to establish priorities regarding the performance and investment assumptions defined for each alternative.

\section{METHODOLOGY}

As mentioned above, this study seeks to identify the main natural gas (NG) consuming countries ordering them based on the information disclosed in the "Oil, Natural Gas and Biofuels Statistical Yearbook 2017," published by the ANP - Brazilian National Agency of Petroleum, Natural Gas and Biofuels (ANP, 2017). The publication is a guide subsidizing the market's stakeholders in planning and decision-making. This study adds significant value to the yearbook's data by applying multi-criteria decision-making (MCDM) methods to order the NG consuming countries, exposing their business potential in this industry. The research developed an approach using the MCDM methods WINGS, TOPSIS, and PROMÉTHÉE II. 
INDEPENDENT JOURNAL OF MANAGEMENT \& PRODUCTION (IJM\&P)

http://www.ijmp.jor.br

v. 12, n. 2, March-April 2021

ISSN: 2236-269X

DOI: 10.14807/ijmp.v12i2.1287

\subsection{Selection of the Set of Alternatives}

The set of alternatives was composed of the 39 NG consuming countries that have data on consumption, production, and reserve published in the ANP's Yearbook 2017 (ANP, 2017) (Table 1).

Table 1: Set of alternatives

\begin{tabular}{|c|c|c|c|c|c|}
\hline \multicolumn{6}{|c|}{ Alternatives } \\
\hline 1 & Canada & 14 & Netherlands & 27 & United Arab Emirates \\
\hline 2 & United States & 15 & Italy & 28 & Iran \\
\hline 3 & Mexico & 16 & Norway & 29 & Algeria \\
\hline 4 & Argentina & 17 & Poland & 30 & Egypt \\
\hline 5 & Brazil & 18 & United Kingdom & 31 & Australia \\
\hline 6 & Colombia & 19 & Romania & 32 & Bangladesh \\
\hline 7 & Peru & 20 & Russia & 33 & China \\
\hline 8 & Trinidad and Tobago & 21 & Turkmenistan & 34 & India \\
\hline 9 & Venezuela & 22 & Ukraine & 35 & Indonesia \\
\hline 10 & Germany & 23 & Uzbekistan & 36 & Malaysia \\
\hline 11 & Azerbaijan & 24 & Saudi Arabia & 37 & Pakistan \\
\hline 12 & Kazakhstan & 25 & Qatar & 38 & Thailand \\
\hline 13 & Denmark & 26 & Kuwait & 39 & Vietnam \\
\hline
\end{tabular}

Source: Elaborated by the authors.

\subsection{Selection of the Set of Criteria and Sub-criteria}

Table 2 shows the criteria and sub-criteria adopted in the study.

Table 2: Set of criteria and sub-criteria

\begin{tabular}{|c|c|c|c|c|}
\hline \multicolumn{2}{|c|}{ Criteria } & $\begin{array}{l}\text { Volume of NG consumption } \\
\text { (billions of } \mathrm{m}^{3} \text { ) }\end{array}$ & $\begin{array}{l}\text { Volume of } \mathrm{NG} \\
\text { production } \\
\text { (billions of } \mathrm{m}^{3} \text { ) }\end{array}$ & $\begin{array}{l}\text { Volume of NG } \\
\text { reserves in } 2016 \\
\text { (trillions of } \mathrm{m}^{3} \text { ) }\end{array}$ \\
\hline \multirow{3}{*}{$\begin{array}{l}\text { Sub- } \\
\text { criteria }\end{array}$} & 1 & $\begin{array}{l}\text { NG consumption variation (percentage) } \\
\text { comparing } 2013 \text { and } 2014 \\
\end{array}$ & $\begin{array}{l}\text { NG production in } 2014 \\
\text { (billions of } \mathrm{m}^{3} \text { ) }\end{array}$ & \multirow{3}{*}{ No subcriteria } \\
\hline & 2 & $\begin{array}{l}\text { NG consumption variation (percentage) } \\
\text { comparing } 2014 \text { and } 2015\end{array}$ & $\begin{array}{l}\text { NG production in } 2015 \\
\text { (billions of } \mathrm{m}^{3} \text { ) }\end{array}$ & \\
\hline & 3 & $\begin{array}{l}\text { NG consumption variation (percentage) } \\
\text { comparing } 2015 \text { and } 2016\end{array}$ & $\begin{array}{l}\text { NG production in } 2016 \\
\text { (billions of } \mathrm{m}^{3} \text { ) }\end{array}$ & \\
\hline
\end{tabular}

Source: Elaborated by the authors.

\subsection{Multi-Criteria Decision-Making Methods: WINGS-TOPSIS-PROMÉTHÉE II}

After establishing the set of alternatives and criteria, this section describes the MCDM methods used to develop the hybrid approach adopted in the study.

\subsubsection{Application of the WINGS Method to Establish Weight of Criteria}

According to Michnik (2013), the WINGS method is appropriate to generate weights for each criterion because its methodology considers each criterion's strength in the sale of NG. It considers the degree of strength of each criterion, as well as the influence the criteria have on each other. 
DOI: 10.14807/ijmp.v12i2.1287

The nature of the criteria selected in this research implies that they are mutually influential. For example, a country's large reserves of NG can influence its NG production; and a country's high NG production can influence its consumption. Each of the criteria studied has a specific strength to turn a country into a potential NG consumer. For example, the consumption of NG in a country is a factor that has more influence in turning it into an NG consumption country than its volume of reserves.

Strength-influence matrix D was created to apply the WINGS method and generate the weight of each criterion (Table 3). The values to evaluate the strength degree in each of the studied systems ranged from 0 to 4 where (0) was no strength; (1) low; (2) moderate; (3) high; and (4) very high strength. The influence of each criterion on the others followed the scale: (0) no influence; (1) little; (2) moderate; (3) high; (4) very high influence.

The reference strength (importance) and the influence observed for each criterion were evaluated based on previous studies and the authors' professional experiences in the oil industry. The reference strength expressed how much the criterion might affect the sale of NG in the world. The reference influence expressed how much one criterion influences another criterion in the sale of NG.

The first criterion evaluated was consumption, which was considered to have a very high degree of strength (4) since the NG consumption in a given region strongly affects sales.

The second criterion, production, received a degree of moderate strength (2) since the NG production in a given region potentially affects sales. The fact that a particular region produces NG may positively or negatively affect sales, but not to the same degree as observed with the consumption variation.

Finally, the criterion of country reserves was considered low (1), because the fact that a location may have NG, does not significantly affect sales.

After adding the degree of strength of each criterion to the system, the study established their degree of mutual influence. As consumption significantly affects production and has no influence on reserves (consumption does not influence the level of reserves, since it is a natural good), the study attributed (3) to the first case and (0) to the latter.

As for production, the degrees of influence attributed were (2) for consumption, because natural gas production can moderately influence consumption since a country can produce and not consume; and (0) for reserves, as natural gas production cannot influence the volume of reserves. 
DOI: $10.14807 /$ ijmp.v12i2.1287

Finally, the degree of influence of reserves was (1) for consumption, because the volume of reserves has little influence on NG consumption; and (3) for production, since having NG reserves highly influences production. Also, a country with reserves may decide not to produce natural gas.

Table 3: Strength-influence matrix D of criteria to apply WINGS method

\begin{tabular}{|c|c|c|c|}
\cline { 2 - 4 } \multicolumn{1}{c|}{} & \multicolumn{3}{c|}{ Matrix D } \\
\hline Criterion & Consumption & Production & Reserves \\
\hline Consumption & 4 & 3 & 0 \\
\hline Production & 2 & 2 & 0 \\
\hline Reserve & 1 & 3 & 1 \\
\hline
\end{tabular}

Source: Elaborated by the authors.

After applying the WINGS method, the net effect value was used (r-c) to designate each criterion's weight. The net effect is the difference in the impact exercised and the impact received for each criterion. Because the net effect values can be either positive or negative, they were squared to eliminate negative values. Then the square root was extracted from the squared net effect values, obtaining all positive net effect values (designated as NEL) to be used when attributing weights for each criterion (Equation 1).

$$
N E L=\sqrt{\left(r_{i}-c_{i}\right)^{2}}
$$

After obtaining the values extracted from Equation 1, they were normalized according to Equation 2 to obtain the weight of each criterion.

$$
w_{i}=\frac{\sqrt{\left(r_{i}-c_{i}\right)^{2}}}{\sum_{i=1}^{n} \sqrt{\left(r_{i}-c_{i}\right)^{2}}}
$$

where wi is the weight of criterion $i$.

\subsubsection{1. $\quad$ Establishing Weights to Criteria and Sub-criteria}

As shown in Table 2, the study used the NG consumption variation for 2014 to 2016, and each year represents a sub-criterion of the criterion 'consumption.' The study used the same years when analyzing production, and each year represents a sub-criterion of the criterion 'production.' The criterion 'reserves' does not have sub-criteria.

To establish the weight of each sub-criterion of 'consumption,' the standard deviation of the countries' NG consumption variation in each year was calculated, according to Equation 3. 
DOI: $10.14807 /$ ijmp.v12i2.1287

$$
S_{s c_{i}}=\sqrt{\frac{\sum\left(x_{i}-\bar{x}\right)^{2}}{n-1}}
$$

where $\mathrm{S}_{s c i}$ is the standard deviation of sub-criterion $i . x_{i}$ is a data from sub-criterion $i$, and $\bar{x}$ is the average data of sub-criterion $i$. Each weight was attributed proportionally to the value of the respective standard deviation. Then, values of the sub-criteria that belong to the same criterion were normalized, creating the variable $u$ (Equation 4).

$$
u_{i}=\frac{S_{s c_{i}}}{\sum_{i=1}^{n} S_{s c_{i}}}
$$

The normalized standard deviation value of each sub-criterion $(u)$ was multiplied by the weight of each criterion designated by the WINGS method, obtaining the weight of each subcriterion (Equation 5). The same procedure was carried out for the criterion 'production.' As the criterion 'reserves' has no sub-criteria, the weight used was that established for the WINGS method.

$$
w_{s c_{i}}=w_{i} * u_{i}
$$

where $w_{s c i}$ is the weight of sub-criterion $i$.

Thus, the criterion that obtained the highest standard deviation was the one with the highest weight. This occurs because, in a given criterion, there are alternatives that performed above de average (which were considered as 'positive'), and alternatives that performed below the average (considered as 'negative')

The criterion that obtained the lowest standard deviation was the one with the lowest weight. In this criterion, the performance of the alternatives was closer to the average, in comparison to the other criteria. Therefore, the performance deviations of the alternatives in comparison to the average must be represented less gradually.

After performing the calculations for the MCMD WINGS method, the net effect values (r-c) were squared to eliminate negative numbers. Then the square root of these values was extracted. Finally, the resulting values were normalized in order to establish the weight of each criterion following Equations 1 and 2 (Table 4).

Table 4: Criteria weights

\begin{tabular}{|c|c|c|}
\hline Criteria & ANE & Wi \\
\hline Consumption & 0.0329 & 0.0803 \\
\hline Production & 0.0535 & 0.1305 \\
\hline Reserves & 0.3235 & 0.7892 \\
\hline
\end{tabular}


DOI: 10.14807/ijmp.v12i2.1287

\begin{tabular}{|l|c|}
\hline$\sum$ & 0.4099 \\
Source: Elaborated by the authors.
\end{tabular}

\subsubsection{Application of the TOPSIS Method: Alternatives Pre-selection}

The alternatives were pre-selected to find the top 15 natural gas (NG) consuming countries within the universe of 39 countries disclosed in the ANP's Yearbook 2017 (ANP, 2017) in order to reduce the number of alternatives (Table 5). The method was used to analyze all alternative's performance in the set of criteria described in Section 3.2. Sub-criteria SC1, SC2, and SC3 are 'benefits' sub-criteria, and SC4, SC5, SC6, and SC7 are considered as 'costs' sub-criteria.

The MCDM TOPSIS method was chosen to pre-select alternatives because it does not perform a pairwise comparison (Hwang \& Yoon, 1981). This method establishes an order for the set of alternatives based on the alternative closest to the positive ideal solution and the farthest from the negative ideal solution.

Thus, the alternative that had the highest NG consumption growth, the lowest production, and the lowest reserves was the alternative that had the best performance in all criteria.

Table 5: Order of the 15 first pre-selected countries

\begin{tabular}{|c|c|c|}
\hline Order & Alternative & $\square$ \\
\hline 1 & Bangladesh & 0.9789 \\
\hline 2 & Peru & 0.9783 \\
\hline 3 & Mexico & 0.9684 \\
\hline 4 & Argentina & 0.9677 \\
\hline 5 & Colombia & 0.9675 \\
\hline 6 & Thailand & 0.9674 \\
\hline 7 & Poland & 0.9671 \\
\hline 8 & Vietnam & 0.9669 \\
\hline 9 & Pakistan & 0.9666 \\
\hline 10 & Kazakhstan & 0.9630 \\
\hline 11 & Italy & 0.9630 \\
\hline 12 & United Kingdom & 0.9626 \\
\hline 13 & Brazil & 0.9612 \\
\hline 14 & Azerbaijan & 0.9601 \\
\hline 15 & Germany & 0.9600 \\
\hline
\end{tabular}

Source: Elaborated by the authors.

\subsubsection{Pre-analysis of the Dominance among Alternatives}

Dominance pre-analysis is a comparison method that simplifies decision-making by eliminating dominated alternatives. Elimination is accomplished by comparing and selecting the alternative in which for all attributes, there is an alternative as good as the dominated one, 
DOI: 10.14807/ijmp.v12i2.1287

and for at least one attribute, the dominated one is worse (Pomerol \& Barba-Romero, 2000; Leão, 2007).

In this phase of the hybrid MCDM WINGS-TOPSIS-PROMÉTHÉE II approach, the study observed whether there is a dominated alternative in the set of 15 alternatives pre-selected by the TOPSIS method (Table 5).

Then, a comparison among the attributes of all alternatives was carried out, excluding from the analysis, those where there were, for all attributes, an alternative as good as the dominated one and at least one attribute where the dominated one is worse. The sub-criteria of consumption variation ( $\mathrm{SC}_{1}, \mathrm{SC}_{2}$, and $\mathrm{SC}_{3}$ ) are sub-criteria of maximization. The ones of production ( $\mathrm{SC}_{4}, \mathrm{SC}_{5}$, and $\left.\mathrm{SC}_{6}\right)$ and proven reserves $\left(\mathrm{SC}_{7}\right)$ are sub-criteria of minimization.

After the pre-analysis of dominance among the 15 countries initially selected using the TOPSIS method, it was possible to obtain the final ranking of the first 12 countries that were the object of study for the application of the PROMÉTHÉE II method (Table 6).

Table 6: Order of the 12 first selected countries

\begin{tabular}{|c|c|c|}
\hline Order & Alternative & $\square$ \\
\hline 1 & Bangladesh & 0.9789 \\
\hline 2 & Peru & 0.9783 \\
\hline 3 & Mexico & 0.9684 \\
\hline 4 & Argentina & 0.9677 \\
\hline 5 & Colombia & 0.9675 \\
\hline 6 & Poland & 0.9671 \\
\hline 7 & Vietnam & 0.9669 \\
\hline 8 & Italy & 0.9630 \\
\hline 9 & United Kingdom & 0.9626 \\
\hline 10 & Brazil & 0.9612 \\
\hline 11 & Azerbaijan & 0.9601 \\
\hline 12 & Germany & 0.9600 \\
\hline
\end{tabular}

Source: Elaborated by the authors.

\subsubsection{Application of the PROMÉTHÉE II Method}

The MCDM PROMÉTHÉE II method was applied to establish the final ordering of the new set of alternatives, i.e., the set of alternatives resulting from the pre-selection established by the TOPSIS method and the exclusion of dominated alternatives.

PROMÉTHÉE II was chosen because it is a method that compares pairs of alternatives in all criteria. The application of the method requires to assign a preference function to each criterion, i.e., the difference in the performance of all alternatives is measured in the range from 0 to 1 . In this methodology, the linear preference criterion was used to measure the difference in performance among the alternatives in all criteria. This procedure was adopted because the 
DOI: 10.14807/ijmp.v12i2.1287

preference function measures the differences among the alternatives by all values between 0 and 1 using only one preference threshold or using the linear preference criterion with indifference zone always with zero indifference threshold (Mladineo, Jajac \& Rogulj, 2016).

According to Mladineo, Jajac, and Rogulj (2016), to calculate the preference threshold of the linear preference criterion, the value of the highest performance of each criterion is subtracted from the value of the worst performance of each criterion (Equation 5).

$$
p_{i}=x_{i}^{+}-x_{i}^{-}
$$

where $p_{i}$ is the preference threshold of criterion $i ; x_{i}{ }^{+}$is the value of the highest performing criterion $i$ and $x_{i}{ }^{-}$is the value of the lowest-performing criterion $i$.

After defining the preference thresholds, the PROMÉTHÉE II method was applied to the set of alternatives using these values as thresholds and the weights of the criteria established by the WINGS method.

Although this study adopted the PROMÉTHÉE II method, it is important to clarify that other multi-criteria methods use a pairwise comparison of alternatives for ordering a set of alternatives, such as the AHP, ANP, MACBETH, TODIM, ELECTRE II, ELECTRE III, and ELECTRE IV methods.

It is noteworthy that the AHP, ANP, and MACBETH methods were not suitable for this study because they perform a different pairwise comparison than the other methods mentioned above. When these methods compare two alternatives $\mathrm{a}$ and $\mathrm{b}$ on a given criterion, the value resulting from the comparison must be the inverse of the value of $b$ and a or vice versa.

This research did not adopt the TODIM method because it uses different forms of measuring when the discrepancies between pairs of alternatives in the criteria studied are positive or negative. This study intended to measure both positive and negative differences in the same way.

The ELECTRE IV method was not chosen because it works with criteria presenting equal weights. As for the methods ELECTRE II and ELECTRE III, the difference among the alternatives' performance in the criteria is measured by the weight value of each criterion when generating the agreement index. The disagreement index, however, is generated only from the value of the most significant difference among the performance of the alternatives in the studied criteria. 
DOI: $10.14807 /$ ijmp.v12i2.1287

Therefore, the PROMÉTHÉE II method was preferred since it works the differences among alternative performances in all criteria. This adds value to the analyzes carried out by stakeholders interested in the natural gas market when observing the ANP's Yearbook 2017 (ANP, 2017) data. The PROMÉTHÉE II method allows considering the value of the differences among pairs of alternatives across all criteria, as well as identically measuring the differences of performance.

\section{DATA ANALYSIS}

\subsection{Countries' Degree of Attractiveness}

In addition to ordering alternatives, the study attributed a degree of attractiveness to each alternative, according to the value of the alternative's net overflow (Table 7).

According to Miettinen (2014), the goal of graphical visualization in multi-criteria problems is to contribute to understanding the data. The decision-maker learns more about the problems, increasing the ability to make better choices. The use of the Visual PROMETHEE® software to generate ranking charts is a form of providing complementary information.

The PROMETHEE Rankings chart generated by the Visual PROMETHEE® software divides the potential values of the net overflow into four equal intervals. That is, the interval ($1 ;+1$ ) is divided into four classification levels containing intervals of 0.5 . Table 7 shows the classification of each net overflow interval from I to V.

Table 7: Intervals of the degree of attractiveness

\begin{tabular}{|c|c|}
\hline Net overflow $(p h i)$ & Degree of attractiveness \\
\hline$[0,5<p h i \leq 1]$ & I \\
\hline$[0<p h i \leq 0,5]$ & II \\
\hline$[-0,5<p h i \leq 0]$ & III \\
\hline$[-1<p h i \leq-0,5]$ & IV \\
\hline$[p h i=-1]$ & V \\
\hline
\end{tabular}

Source: Elaborated by the authors.

Table 7 demonstrates that the degree of attractiveness I is attributed in the case of any country obtaining net overflow between the interval $(+0.5 ;+1)$. The other classifications were assigned to intervals of 0.5 between the values of the highest and lowest possible net overflow when applying the PROMÉTHÉE II method. Figure 1 shows the degree of attractiveness attributed to each country studied. 


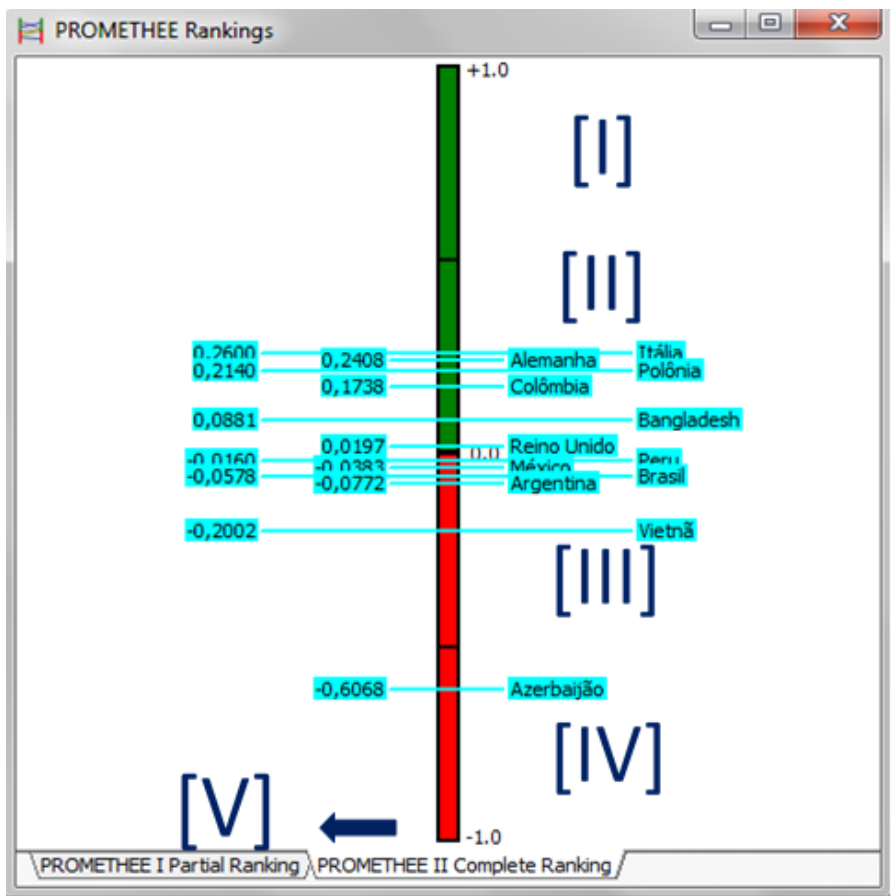

Figure 1: Degree of attractiveness attributed to countries according to the PROMÉTHÉE II Method

Source: Edited from the Visual PROMETHEE® software

Figure 1 shows the degree of attractiveness attributed to each country. It shows that countries are ranked II and IV with relatively close performance values. To help identify each country's attractiveness, Table 8 presents their ordering, net overflow values, and degree of attractiveness.

Table 8: Countries ordering and degree of attractiveness

\begin{tabular}{|c|c|c|c|}
\hline Order & Country & Net overflow & Degree of attractiveness \\
\hline 1 & Italy & 0.2600 & II \\
\hline 2 & Germany & 0.2408 & II \\
\hline 3 & Poland & 0.2140 & II \\
\hline 4 & Colombia & 0.1738 & II \\
\hline 5 & Bangladesh & 0.0881 & II \\
\hline 6 & United Kingdom & 0.0197 & III \\
\hline 7 & Peru & -0.0160 & III \\
\hline 8 & Mexico & -0.0383 & III \\
\hline 9 & Brazil & -0.0578 & III \\
\hline 10 & Argentina & -0.0772 & IV \\
\hline 11 & Vietnam & -0.2002 & -0.6068 \\
\hline 12 & Azerbaijan & & \\
\hline
\end{tabular}

Source: Elaborated by the authors.

Table 8 demonstrates that all countries have a degree of attractiveness II, III, or IV. No country had the best performance (I) or the worst performance in all criteria (V).

The assessment of each country's attractiveness provided important complementary information about their performance. For example, Table 8 shows that Italy is positioned in the first place, even though it does not reach the degree of attractiveness I, while Brazil is 
INDEPENDENT JOURNAL OF MANAGEMENT \& PRODUCTION (IJM\&P)

http://www.ijmp.jor.br

v. 12, n. 2, March-April 2021

ISSN: 2236-269X

DOI: 10.14807/ijmp.v12i2.1287

positioned in ninth place but has the same degree of attractiveness as other countries in a higher position.

\subsection{Strengths and Weaknesses of each Country}

At this stage, the PROMETHEE Rainbow chart generated by the Visual PROMETHEE® software analyzed the strengths and weaknesses of each country.

The chart (Figure 2) allows a comparative analysis of the performance of the subcriteria for each country, i.e., it was possible to visually identify in each country the sub-criteria in which they had better and worse performances compared to other countries.

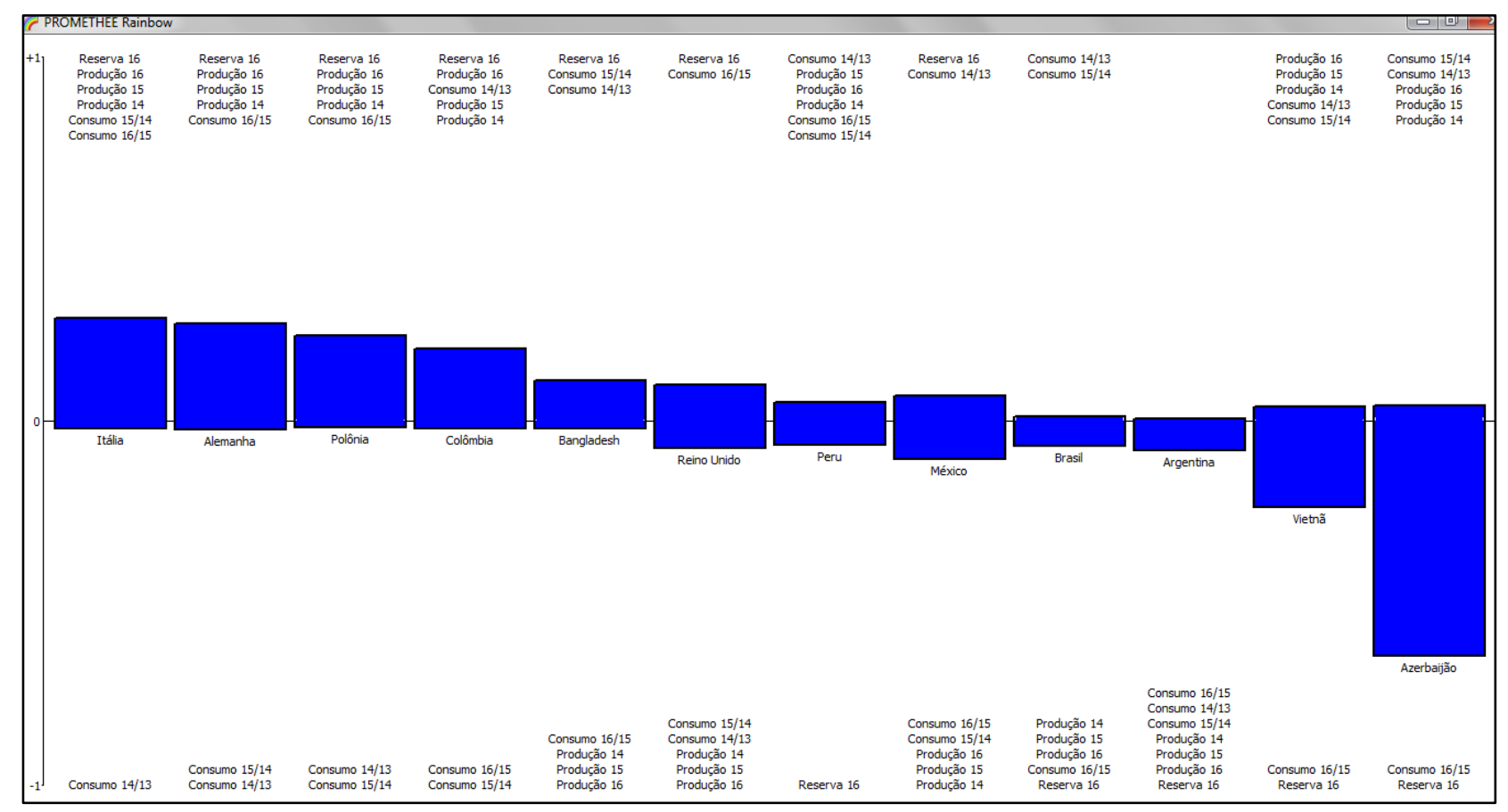

Figure 2: Strengths and weaknesses of each country Source: Visual PROMETHEE® software.

Italy holds the 1st place but does not show the best performance in all sub-criteria. Some countries, for example, have a higher percentage of variation in consumption than Italy when comparing 2013 and 2014 (SC1), and this is a maximizing sub-criterion.

In addition, it was also possible to verify that the 11th and 12th positions have the same strengths and weaknesses. However, Vietnam (11th) stood out in the performance of subcriteria. 
ISSN: $2236-269 X$

DOI: 10.14807/ijmp.v12i2.1287

\subsection{Chart of the Countries' Networks}

Another chart the software provides is the PROMETHEE network. A chart used to support decision-making by presenting the position of each alternative in relation to the others within the set of alternatives studied.

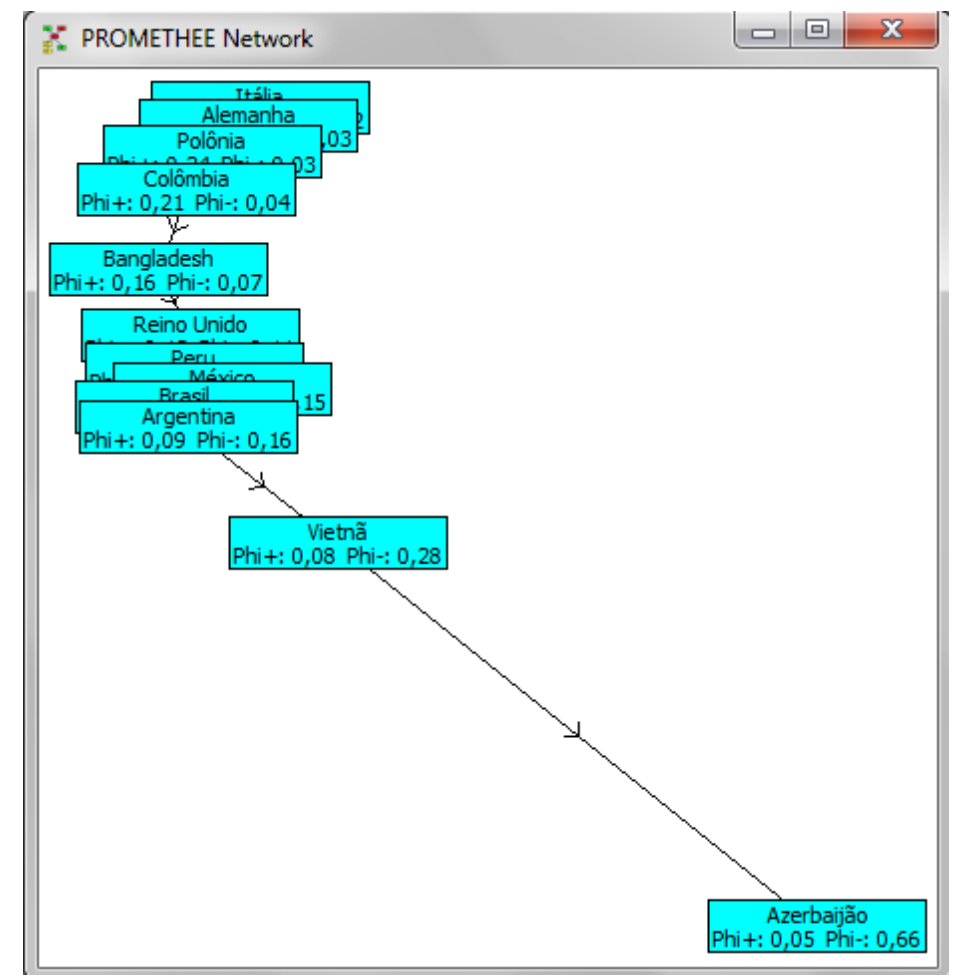

Figure 3: Chart of countries’ networks according to the PROMÉTHÉE II method Source: Visual PROMETHEE ${ }^{\circ}$ software.

Multi-criteria decision-making methods (MCDM) consist of a set of tools that assist the decision-maker. The visual features, such as the PROMETHEE Rankings (Figure 1) and the networks chart (Figure 3), are a significant contribution.

The networks chart visually demonstrated Italy’s prominence in the first position, even when the other countries from the second to the sixth positions present the same degree of attractiveness as Italy (II).

When analyzing the other positions in the ranking, it was observed that the country in the fifth position, Bangladesh, stands out from the others. The countries from the seventh to the eleventh positions present the same degree of attractiveness as Bangladesh (Figure 1) but appear in a separate block. It is worth mentioning that the UK, Peru, Mexico, Brazil, and Argentina were in very close positions, unlike Vietnam and Azerbaijan.

\section{FINAL CONSIDERATIONS}


INDEPENDENT JOURNAL OF MANAGEMENT \& PRODUCTION (IJM\&P)

http://www.ijmp.jor.br

v. 12, n. 2, March-April 2021

ISSN: $2236-269 X$

DOI: $10.14807 /$ ijmp.v12i2.1287

This study introduced a hybrid multi-criteria decision-making (MCDM) approach applied to the natural gas (NG) industry. The aim was to contribute to the planning and decision-making by governments, economic agents, and other stakeholders operating in the international natural gas market. The findings demonstrated that hybrid MCDMs, when adequately used, may be an efficient tool for robust analysis, supporting the ordering of NG consuming countries and offering subsidies to promote sales and commercialization strategies in the global market.

The study established the order to a set of NG consuming countries observing their potential for business, analyzing seven quantitative sub-criteria: variation in NG consumption (percentage) comparing the years 2013 to 2016; NG production between 2014 and 2016; and proven reserves of NG in 2016. The data used in this research was collected from the document “Oil, Natural Gas and Biofuels Statistical Yearbook 2017,” published by the ANP - Brazilian National Agency of Petroleum, Natural Gas and Biofuels (ANP, 2017).

The hybrid MCDM approach adopted in this research first used the WINGS method to attribute the weights of each criterion. Second, the TOPSIS method was applied to pre-select the countries closest to being a potential NG global consumer. After, a dominance pre-analysis among the alternatives was carried out to exclude dominated alternatives in the first set. Finally, the PROMÉTHÉE II method was used to establish the final ranking of the countries.

The application of the hybrid MCDM approach presented in this paper established an order for the countries listed in the ANP's Yearbook 2017 (ANP, 2017) based on their characteristics, suggesting their potential as NG consuming countries. The study added value to the data presented by ANP. As the Brazilian agency displays the characteristics of the countries separately, the approach allows a comparative analysis observing the data on consumption, production, and reserves simultaneously.

The analysis of the criteria based on this hybrid MCDM approach provides a better understanding of the factors that facilitate decision-making. These factors were observed in the charts generated by the Visual PROMETHEE® software and brought sensitivity to the countries final ranking. Therefore, the approach provided a degree of attractiveness to each country, and allowed learning each country's position in the set of alternatives and observing their particular strengths and weaknesses in relation to the others.

Thus, this hybrid MCDM approach proved to be reliable in meeting the objectives of this study. The research showed a new way to analyze the data released by the ANP in its 
INDEPENDENT JOURNAL OF MANAGEMENT \& PRODUCTION (IJM\&P)

http://www.ijmp.jor.br

v. 12, n. 2, March-April 2021

ISSN: 2236-269X

DOI: 10.14807/ijmp.v12i2.1287

yearbook, improving the publication's capacity to subsidize decision-making regarding the order of priority when encouraging natural gas sales in the global market.

\section{REFERENCES}

Anp (2017). Anuário Estatístico Brasileiro do Petróleo, Gás Natural e Biocombustíveis 2017. Available: http://www.anp.gov.br/publicacoes/anuario-estatistico/3819-anuarioestatistico-2017. Access: September 13, 2018.

Bana E Costa, C. A., Corte, J. M., \& Vansnick, J. C. (2005). On the Matemathical foundations of MACBETH. In: Figueira, J., \& Greco, S. (eds.).. Multiple Criteria Decision Analysis: State of the Art Surveys. New York: Springer, 78, 409-442.

Barba-Romero, S., \& Promerol, J. C. (1997). Decisiones multicriterio: fundamentos teóricos y utilización prática. Madrid: Servicio de Publicaciones de la Universidad de Alcalá.

Belton, V., \& Stewart, T. J. (2002). Multiple criteria decision analysis: an integrated approach. Boston: Kluwer Academic Press,1-5.

Bilgin, M. (2009). Geopolitics of European natural gas demand: Supplies from Russia, Caspian and the Middle East. Energy Policy, 37(11), 4482-4492.

Brans, J. P., Vincke, P., \& Mareschal, B. (1986). How to select and how to rank projects: The PROMETHEE method. European Journal of Operational Research, 24, 228-238.

Energy Information Administration - EIA (2009). International Energy Outlook 2009. DOE/EIA-0484.

Energy Information Administration - EIA (2010). International Energy Outlook 2010. DOE/EIA-0484.

Energy Information Administration - EIA (2017). Annual Energy Outlook 2017: with projections to 2050. Available: https://www.eia.gov/outlooks/aeo/pdf/0383(2017)..pdf.

Access: September 04, 2018.

Energy Information Administration - EIA (2018). Annual Energy Outlook 2018: with projections to 2050. Available: https://www.eia.gov/outlooks/aeo/pdf/AEO2018.pdf. Acess: March 13, 2019.

European Commission - EC (2008). Second Strategic Energy Review: Securing our Energy Future.

European Commission - EC (2009). The January 2009 Gas Supply Disruption to the EU: An Assessment, Commission Staff Working Document Accompanying Document.

Faramawy, S., Zaki, T., \& Sakr, A. (2016). Natural gas origin, composition, and processing: A review. Journal of Natural Gas Science and Engineering, 34, 34-54, June. 
Gomes, L. F. A. M., Araya, M. C. G., \& Carignano, C. (2004). Tomada de decisões em cenários complexos: introdução aos métodos discretos do apoio multicritério à decisão. São Paulo: Pioneira Thomson Learning.

Gomes, L. F. A. M., Gomes, C. F. S., \& Almeida, A. T. (2006). Tomada de decisão gerencial: enfoque multicritério. $2^{\mathrm{a}}$ edição. São Paulo: Atlas.

Gomes, L. F. A. M., \& Maranhão, F. J. C. (2008). A Exploração de gás natural em Mexilhão: análise multicritério pelo método TODIM. Pesquisa Operacional, 28(3), 491-509, Set./Dez. 2008.

Gomes, L. F. A. M., \& Gomes, C. F. S. (2014). Tomada de decisão gerencial: enfoque multicritério. $5^{\text {a }}$ ed. São Paulo: Atlas.

Gomes, L. F. A. M., \& Maranhão, F. J. C. (2008). A Exploração de gás natural em Mexilhão: análise multicritério pelo método TODIM. Pesquisa Operacional, 28(3), 491-509,

September/December.

Helen, H. (2010). The EU's Energy Security Dilemma with Russia. University of Leeds.

Polis Journal, 4, 1-40, Winter.

Hwang, C. L., \& Yoon, K. (1981). Multiple Attribute Decision Making: Methods and Applications - A State-of-the-Art Survey. Berlin: Springer-Verlag.

International Energy Agency - IEA. (2017). GAS 2017: Analyis and Forecasts to 2022. Market Report Series.

International Energy Agency - IEA. (2018). World Energy Outlook 2018. International Energy. Agency: France.

Keeney, R. L., \& Raiffa, H. (1993). Decisions With Multiple Objectives: Preferences and Value Tradeoffs. Cambridge: Cambridge University Press.

Khosravanian, R., \& Wood. D. A. (2016). Selection of high-rate gas well completion designs applying multicriteria decision making and hierarchy methods. Journal of Natural Gas Science and Engineering, 34, 1004-1016.

Leão JR., J. C. F. (2007). Seleção de Carteira de Projetos Exploratórios em Etapas: Agrupamento, Corte e Ordenação. Thesis (Master in Administration). - Rio de Janeiro, Faculdades Ibmec, Rio de Janeiro. 327.

Mac Kinnon, M. A; Brouwer, J., \& Samuelsen, S. (2018). The role of natural gas and its infrastructure in mitigating greenhouse gas emissions, improving regional air quality, and renewable resource integration. Progress in Energy and Combustion Science, 64, 62- 92, January.

Michnik, J. (2013). Weighted Influence Non-linear Gauge System (WINGS). - An analysis method for the systems of interrelated components. European Journal of Operational Research, 228(3), 536-544, 2013.

Miettinen, K. (2014). Survey of methods to visualize alternatives in multiple criteria decision making problems. Operations Research Spectrum, 36(1), 3-37. 
Mladineo, M; Jajac, N., \& Rogulj, K. (2016). A simplified approach to the promethee method for priority setting in management of mine action projects. Croatian Operational Research Review, 7(2), Prosinac.

Neves, R. B., Pereira, V., \& Costa, H. G. (2015). Auxílio multicritério à decisão aplicado ao planejamento e gestão na indústria de petróleo e gás. Production, 25(1), 43-53, January/March.

Pomerol, J. C., \& Barba-Romero, S. (2000). Multicriterion Decision in Management: Principles and Practice. Boston/Dordrecht/London: Kluwer Academic Publishers.

Radetzki, M. (1999). European natural gas: market forces will bring about competition in any case. Energy Policy, 27(1), 17-24.

Romero, C. (1993). Teoría de la decisión multicriterio: conceptos, técnicas y aplicaciones. Madrid: Alianza. p. 195.

Roy, B., \& Bouyssou, D. (1993). Aide multicritère à la decision: methods et cas. Paris: Economica.

Saaty, T. L. (1980). The Analytic Hierarchy Process. New York: McGraw-Hill International.

Santos, E. M., Zamalloa, G. C., Villanueva, L. D., Fagá, M. T. D. (2002). Gás natural: estratégias para uma energia nova no Brasil. São Paulo: Annablume. 1, 348 p.

Vincke, P. H. (1989). L’aide multicritère à la dècision. Bruxelles: Éditions de l’Université de Bruxelles. 179 p.

Zhong, M., \& Bazilian, M. D. (2018). Contours of the energy transition: Investment by international oil and gas companies in renewable energy. The Electricity Journal, 31(1), 8291, January/February. 